\title{
SISTEM PENDUKUNG KEPUTUSAN PENANGANAN GIZI BALITA DENGAN METODE FUZZY MAMDANI
}

\author{
Heru Budi Kusumo ${ }^{1)}$, Dwi Remawati ${ }^{2)}$, Yustina Retno Wahyu Utami ${ }^{3)}$ \\ ${ }^{1)}$ Program Studi Teknik Informatika, STMIK Sinar Nusantara Surakarta \\ ${ }^{2)}$ Program Studi Teknik Informatika, STMIK Sinar Nusantara Surakarta \\ ${ }^{3)}$ Program Studi Teknik Informatika, STMIK Sinar Nusantara Surakarta \\ ${ }^{1)}$ Herubudikusuma@gmail.com, ${ }^{2)}$ dwirema@ @inus.ac.id, ${ }^{3)}$ yustina_retno@ sinus.ac.id
}

\begin{abstract}
Decision Support System is a branch of artificial intelligence used to help make decisions in semi-structured cases, where it is not known exactly how decisions should be made. In this research, the design and making of decision support system that is used to help determine the nutritional status of children with weight input, age, height, head circumference, nutrition value of toddlers and the output of nutritional status of children under five and their handling. The problem of data uncertainty in decision support system is solved by using fuzzy mamdani method. The existence of data uncertainty in the process can occur because of the differences in existing calculations on the system. The process of determining the nutritional status of this decision support system is begun by entering the input data of toddlers, where the system will display some variables that have been made then start the calculation with the application. The end result of this research is decision support system to do nutritional handling in toddler along with their nutrition result. The calculations show the level of confidence in the system of nutritional status of the toddler and from the results of this study obtained the system accuracy of $83.33 \%$ of the 18 test data that has been tested is obtained. Therefore, it can be concluded that decision support system produces a good examination.
\end{abstract}

Keywords: Decision Support System, Fuzzy Mamdani, Underfive Nutrition

\section{PENDAHULUAN}

Pada sebagian masyarakat sekarang ini, masih terdapat banyak balita yang masih kekurangan gizi seperti kurangnya kandungan protein, energi, asupan kalori, lemak, karbohidrat, serat, zat besi dan kalsium pada tubuh balita yang mungkin dapat mengganggu kesehatan balita pada saat masa pertumbuhan si balita tersebut. Maka akan timbul masalah seperti gangguan gizi buruk pada balita, yang mengakibatkan banyaknya kasus kematian pada balita yang kekurangan gizi.

Gizi buruk adalah suatu kondisi dimana seseorang dinyatakan kekurangan nutrisi, atau dengan ungkapan lain status gizi atau nutrisinya berada dibawah standar rata-rata. Nutrisi yang dimaksud bisa berupa protein, karbohidrat dan kalori. Di Indonesia, kasus KEP (Kurang Energi Protein) adalah salah satu masalah gizi utama yang banyak dijumpai pada balita (Dian, P. S., \& Sri. , 2015).

Proses penanganan gizi buruk pada balita membutuhkan waktu yang cukup lama dalam memeriksa dan menunggu hasil pemeriksaan. Penanganan gizi buruk pada balita merupakan suatu hal yang patut dijadikan perhatian lebih sehingga mengurangi resiko tidak optimalnya suatu penanganan di sebuah rumah sakit. Pada tahap pengambilan keputusan dengan metode fuzzy diperlukan kriteria yang akan menentukan kondisi balita yang akan digunakan untuk menentukan status gizi balita seperti umur balita, berat badan, panjang badan dan nilai gizinya (Lumbangaol \& Rosaria, 2013).

Permasalahan yang kurang efisien di dalam menentukan proses penanganan gizi buruk pada balita di Puskesmas Ngemplak Boyolali dan kurangnya pengetahuan teknologi untuk membantu penanganan gizi balita di Puskesmas Ngemplak Boyolali menjadikan 
alasan peneliti untuk membuatkan aplikasi yang digunakan untuk proses penanganan gizi buruk pada balita. Aplikasi tersebut mengacu pada asupan gizi yang dibutuhkan untuk dijadikan tolak ukur pada proses penanganan gizi pada balita.

\section{TINJAUAN PUSTAKA}

\subsection{Gizi}

Gizi adalah elemen yang terdapat dalam makanan dan dapat dimanfaatkan secara langsung oleh tubuh seperti halnya karbohidrat, protein, lemak, vitamin, mineral, dan air. Gizi yang seimbang dibutuhkan oleh tubuh, terlebih pada balita yang masih dalam masa pertumbuhan. Dimasa tumbuh kembang balita yang berlangsung secara cepat dibutuhkan makanan dengan kualitas dan kuantitas yang tepat dan seimbang. Gizi Balita adalah hal paling utama yang harus diperhatikan oleh orang tua jika ingin tumbuh kembang putra putrinya maksimal (Kusumadewi \& Purnomo, 2004).

\subsection{Sistem Pendukung Keputusan}

SPK digunakan dalam pengambilan keputusan. Sistem Pendukung Keputusan (SPK) menggunakan CBIS (Computer Based Informmation System) yang fleksibel, interaktif, dan dapat diadaptasi, yang dikembangkan untuk mendukung solusi atas masalah manajemen spesifikasi yang tidak terstruktur. Menurut Turban (2005) dalam bukunya sebagai sistem pendukung keputusan (SPK) atau Decision Support System (DSS), merumuskan bahwa sistem pendukung keputusan adalah sebuah sistem yang mampu memberikan kemampuan pemecahan masalah dengan kondisi semi terstuktur, dan tak stuktur. Sistem ini digunakan untuk membantu pengembalian keputusan dalam situasi semi terstuktur dan situasi yang tidak stuktur, dimana tak seorangpun tahu pasti bagaimana keputusan seharusnya dibuat (Lumbangaol \& Rosaria, 2013).

\subsection{Sistem Data Mining}

Data Mining merupakan suatu cara dalam memberikan nilai analisa dari suatu permasalah semi automatisasi. Tugas data mining sebenarnya adalah analisis otomatis atau semi-otomatis jumlah besar data untuk mengekstrak pola yang menarik yang sebelumnya tidak diketahui seperti kelompok catatan data (analisis cluster), catatan yang tidak biasa (deteksi anomali) dan dependensi (aturan asosiasi pertambangan). Hal ini biasanya melibatkan penggunaan teknik database seperti indeks spasial. Pola ini kemudian dapat dilihat sebagai semacam ringkasan dari input data, dan dapat digunakan dalam analisis lebih lanjut atau, misalnya, dalam pembelajaran mesin dan analisis prediktif. Baik pengumpulan data, penyusunan data, atau interpretasi hasil dan pelaporan merupakan bagian dari langkah data mining, tetapi milik proses KDD secara keseluruhan sebagai langkah-langkah tambahan. Dalam Data Mining terdapat Clusstering (Damayanti, Setyaningsih, \& Qur'ania, 2014).

\subsection{Metode Fuzzy Mamdani}

Metode Mamdani sering juga dikenal dengan nama metode Max-Min metode ini diperkenalkan oleh Ebrahim Mamdani pada tahun 1975. Metode Mamdani paling sering digunakan dalam aplikasi-aplikasi karena strukturnya yang sederhana, yaitu menggunakan operasi MIN-MAX atau MAX-PRODUCT. (Kusumadewi \& Purnomo, 2004).

Cara kerja logika Fuzzy Mamdani sebagai berikut :

Untuk mendapatkan output, diperlukan empat tahapan berikut :

1. Fuzzyfikasi.

2. Pembentukan basis pengetahuan fuzzy). 
3. Aplikasi fungsi implikasi menggunakan fungsi MIN dan Komposisi antar-rule menggunakan fungsi MAX (menghasilkan himpunan fuzzy baru).

4. Defuzzyfikasi menggunakan metode Centroid.

$$
z^{*}=\frac{\int_{z} z \mu(z) d z}{\int_{z} \mu(z) d z}
$$

Untuk domain kontinu, dengan $\mathrm{Z}$ adalah nilai hasil defuzzyfikasi dan $\mu(Z)$ adalah derajat keanggotaan titik tersebut, sedangkan $Z$ adalah nilai domain ke-i. (Mubarok, MN \& Abadi, AM, 2015)

\subsection{MySQL}

MySQL adalah sebuah perangkat lunak sistem manajemen basisdata SQL (DataBase Management System ) atau DBMS dari sekian banyak DBMS seperti Oracle, MS SQL, Postagre SQL, dan lain-lain. MySQL merupakan DBMS yang multithread, multi-user yang bersifat garis bawah lisensi GNU General Public Licence (GPL). MySQL bersifat gratis atau open source sehingga bisa digunakan secara gratis. Pemograman PHP juga sangat mendukung / support dengan database MySQL (Hermaduanti \& Kusumadewi, 2008).

\subsection{PHP}

PHP singkatan dari PHP: Hypertext Preprocessor yaitu bahasa pemograman web server-side yang bersifat open source. PHP merupakan script yang terintegrasi dengan HTML dan berada pada server (server side HTML embedded scripting). PHP adalah script yang digunakan untuk membuat halaman website yang dinamis. Dinamis berarti halaman yang akan ditampilkan dibuat saat halaman itu diminta oleh client. Mekanisme ini menyebabkan informasi yang diterima client selalu yang terbaru / up to date.Semua script PHP dieksekusi pada server dimana script tersebut dijalankan (Permatasari, 2015).

\section{METODE PENELITIAN}

Metode penelitian yang digunakan adalah dengan menggabungkan data, primer serta data sekunder. Sedangkan metode pengumpulan data dilakukan dengan wawancara, observasi serta studi pustaka. Perancangan sistem menggunakan DAD (Diagram Alir Data). Algoritma yang digunakan adalah Algoritma Fuzzy Mamdani.

\section{IV.HASIL DAN PEMBAHASAN}

\subsection{Analisa Sistem}

Kebutuhan masukan dari sistem berupa gizi buruk, gizi normal, dan obesitas pada balita. Hasil dari diagnosa atau riwayat balita yang terkena gizi buruk, normal, dan obesitas di Puskesmas Ngemplak Boyolali sebagai dasar pembuatan himpunan fuzzy. Himpunan fuzzy untuk setiap variable yaitu:

1. Variabel umur/usia (dalam Tahun)

Adapun himpunan fuzzy untuk variabel umur dapat dilihat pada Gambar 1. 


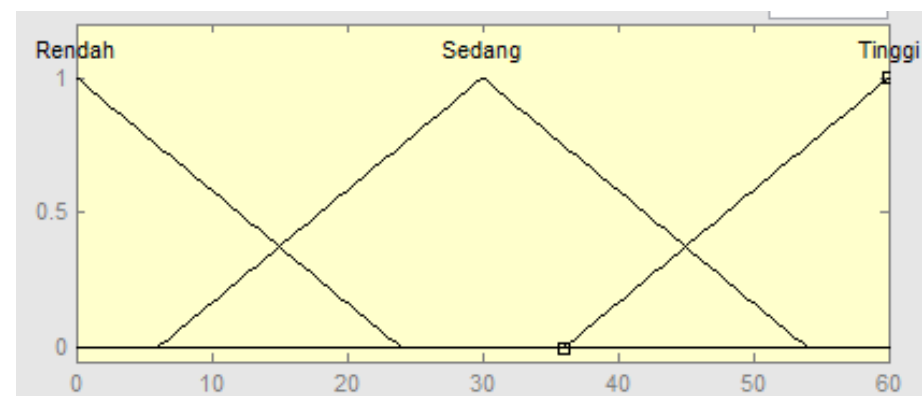

Gambar 1. Grafik Himpunan Fuzzy Umur / Usia

Dengan fungsi keanggotaan :

$$
\begin{aligned}
& \mu \text { Rendah }[X]= \begin{cases}(24-\mathrm{X}) /(24-0), & 0 \leq \mathrm{x} \leq 24 \\
0, & \mathrm{x} \geq 24\end{cases} \\
& \mu \text { Sedang }[\mathrm{X}]= \begin{cases}0, & \mathrm{x} \leq 6 \text { atau } \mathrm{x} \geq 54 \\
\mathrm{x}-6 / 30-6, & 6 \leq \mathrm{x} \leq 24 \\
54-\mathrm{x} / 54-30, & 30 \leq \mathrm{x} \leq 54 \\
\mathrm{x}-48 / 60-48 & 48 \leq \mathrm{x} \leq 60\end{cases} \\
& \mu \text { Tinggi }[\mathrm{X}]= \begin{cases}0, & \mathrm{x} \leq 48 \\
\mathrm{x}-48 / 60-48 & 48 \leq \mathrm{x} \leq 60\end{cases}
\end{aligned}
$$

2. Variabel Berat Badan (dalam Kg)

a. Jenis kelamin perempuan

Himpunan fuzzy untuk variabel berat badan yang berjenis kelamin perempuan dapat dilihat pada Gambar 2.

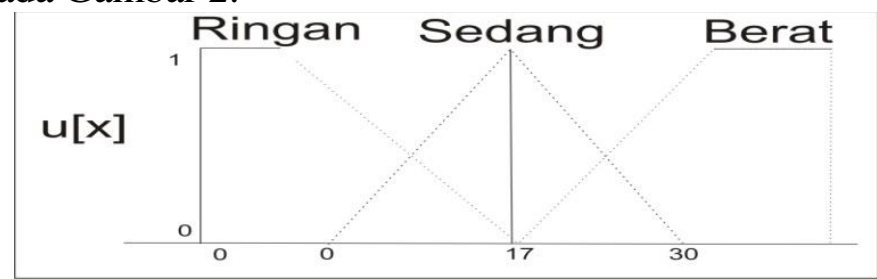

Gambar 2. Himpunan Fuzzy Berat Badan Kelamin Perempuan

Dengan fungsi keanggotaan :

$$
\begin{aligned}
& \mu \text { Ringan }[X]= \begin{cases}1, & x \leq 0.5 \\
17-x / 17-0.5, & 0.5 \leq x \leq 17 \\
0, & x \geq 17\end{cases} \\
& \mu \text { Sedang }[X]= \begin{cases}0, & x \leq 0.5 \text { atau } x \geq 30 \\
x-0.5 / 17-0.5 & 0.5 \leq x \leq 17 \\
30-x / 30-17, & 17 \leq x \leq 30\end{cases} \\
& \mu \text { Berat }[X]= \begin{cases}0, & x \leq 17 \\
x-17 / 30-17, & 17 \leq x \leq 30 \\
1, & x \geq 30\end{cases}
\end{aligned}
$$

b. Jenis kelamin laki-laki

Himpunan fuzzy untuk variabel berat badan yang berjenis kelamin laki-laki dapat dilihat pada Gambar 3. 


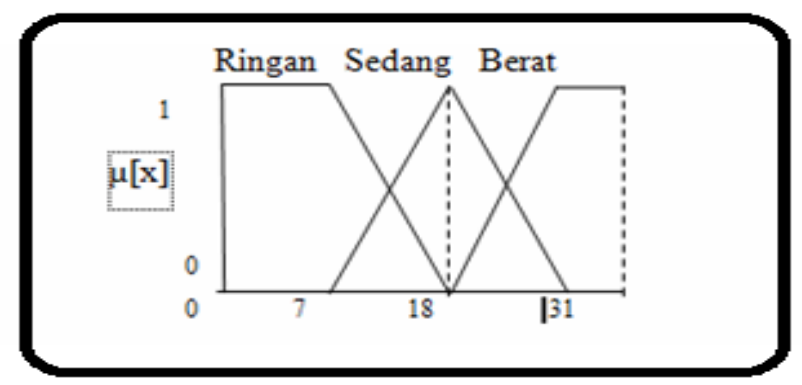

Gambar 3. Himpunan Fuzzy Berat Badan Jenis Kelamin Laki - Laki Dengan fungsi keanggotaan :

$$
\begin{aligned}
& \mu \text { Ringan }[X]= \begin{cases}1, & x \leq 7 \\
18-x / 18-7, & 7 \leq x \leq 18 \\
0, & x \geq 18\end{cases} \\
& \mu \text { Sedang }[X]= \begin{cases}0, & x \leq 7 \text { atau } x \geq 31 \\
x-7 / 18-7, & 7 \leq x \leq 18 \\
31-x / 31-18, & 18 \leq x \leq 31\end{cases} \\
& \mu \text { Berat }[X]= \begin{cases}0, & x \leq 18 \\
x-18 / 31-18, & 18 \leq x \leq 31 \\
1, & x \geq 31\end{cases}
\end{aligned}
$$

3. Variabel panjang badan (dalam $\mathrm{Cm}$ )

a. Jenis kelamin perempuan

Himpunan fuzzy untuk variabel panjang badan yang berjenis kelamin perempuan dapat dilihat pada Gambar 4.

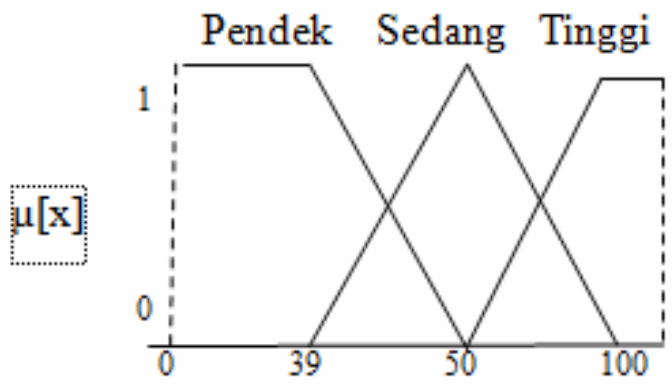

Gambar 4. Himpunan Fuzzy Panjang Badan Perempuan Dengan fungsi keanggotaan :

$$
\begin{aligned}
& \mu \text { Pendek }[X]= \begin{cases}1, & x \leq 39 \\
50-x / 50-39, & 39 \leq x \leq 50 \\
0, & x \geq 50\end{cases} \\
& \mu \text { Sedang }[X]= \begin{cases}0, & x \leq 39 \text { atau } x \geq 100 \\
x-39 / 50-39, & 39 \leq x \leq 50 \\
110-x / 100-50, & 50 \leq x \leq 100\end{cases}
\end{aligned}
$$




$$
\mu \text { Tinggi }[X]= \begin{cases}0, & x \leq 50 \\ x-50 / 100-50, & 50 \leq x \leq 100 \\ 1, & x \geq 100\end{cases}
$$

b. Jenis kelamin laki-laki

Himpunan fuzzy untuk variabel panjang badan yang berjenis kelamin laki-laki dapat dilihat pada Gambar 5.

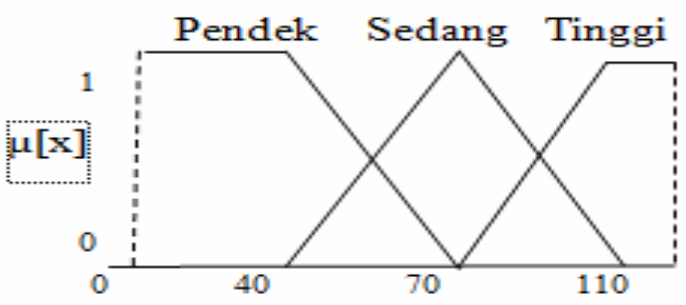

Gambar 5. Himpunan Fuzzy Panjang Badan Laki Laki

Dengan fungsi keanggotaan :

$$
\begin{aligned}
& \mu \text { Pendek }[\mathrm{X}]= \begin{cases}1, & \mathrm{x} \leq 40 \\
70-\mathrm{x} / 70-40, & 40 \leq \mathrm{x} \leq 70 \\
0, & \mathrm{x} \geq 70\end{cases} \\
& \mu \text { Sedang }[\mathrm{X}]= \begin{cases}0, & \mathrm{x} \leq 40 \text { atau } \mathrm{x} \geq 110 \\
\mathrm{x}-40 / 70-40, & 40 \leq \mathrm{x} \leq 70 \\
110-\mathrm{x} / 110-70, & 70 \leq \mathrm{x} \leq 110\end{cases} \\
& \mu \text { Tinggi }[\mathrm{X}]= \begin{cases}0, & \mathrm{x} \leq 70 \\
\mathrm{x}-70 / 110-70, & 70 \leq \mathrm{x} \leq 110 \\
1, & \mathrm{x} \geq 110\end{cases}
\end{aligned}
$$

4. Variabel Lingkar Kepala

a. Jenis kelamin laki - laki

Himpunan fuzzy untuk variabel lingkar kepala yang berjenis kelamin laki - laki dapat dilihat pada Gambar 6.

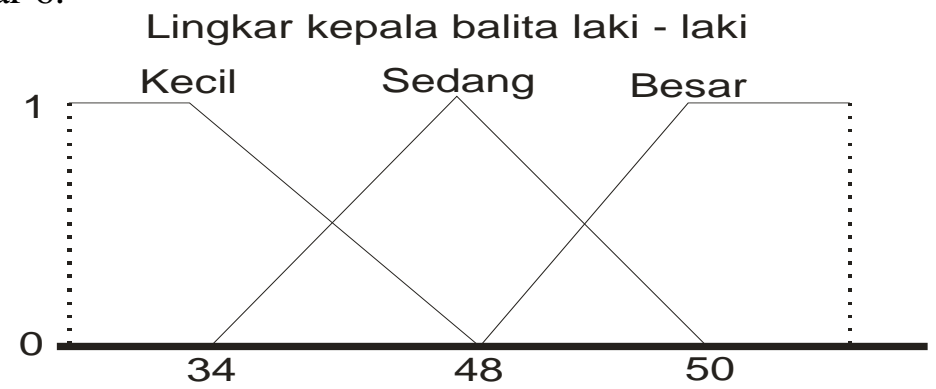

Gambar 6. Himpunan Fuzzy Mamdani Lingkar kepala laki - laki

Dengan fungsi keanggotaan :

$$
\mu \operatorname{Kecil}[X]= \begin{cases}1, & x \leq 34 \\ 48-x / 48-34, & 34 \leq x \leq 48 \\ 0, & x \geq 48\end{cases}
$$




$$
\begin{aligned}
& \mu \text { Sedang }[X]= \begin{cases}0, & x \leq 34 \text { atau } x \geq 50 \\
x-34 / 48-34, & 34 \leq x \leq 48 \\
50-x / 50-48, & 48 \leq x \leq 50\end{cases} \\
& \mu \text { Besar }[X]= \begin{cases}0, & x \leq 48 \\
x-48 / 50-48, & 48 \leq x \leq 50 \\
1, & x \geq 50\end{cases}
\end{aligned}
$$

b. Jenis kelamin perempuan

Himpunan fuzzy untuk variabel lingkar kepala yang berjenis kelamin perempuan dapat dilihat pada Gambar 7.

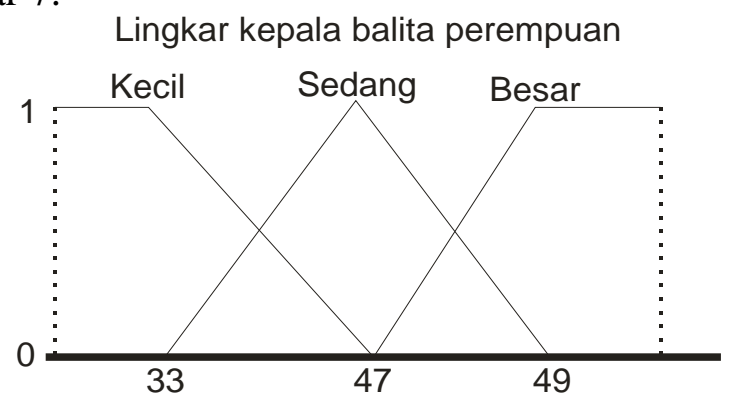

Gambar 7. Himpunan Fuzzy Mamdani Lingkar kepala perempuan Dengan fungsi keanggotaan :

$$
\begin{aligned}
& \mu \text { Kecil }[X]= \begin{cases}1, & x \leq 33 \\
47-x / 47-33, & 33 \leq x \leq 47 \\
0, & x \geq 47\end{cases} \\
& \mu \text { Sedang }[X]= \begin{cases}0, & x \leq 49 \\
x-33 / 47-49, & 33 \leq x \leq 47 \\
49-x / 49-47, & 47 \leq x \leq 49\end{cases} \\
& \mu \text { Besar }[X]= \begin{cases}0, & x \leq 47 \\
x-47 / 49-47, & 47 \leq x \leq 49 \\
1, & x \geq 49\end{cases}
\end{aligned}
$$

Dalam contoh kasus di Puskemas Ngemplak Boyolali tepatnya di ruang IGD terdapat sebuah kasus balita dengan gejala diare yang sudah lama di derita dengan kondisi lemah. Balita tersebut berjenis kelamin perempuan dan berumur 1 tahun dengan berat badan $4 \mathrm{~kg}$ dan panjang badan $50 \mathrm{~cm}$ dan lingkar kepala $37 \mathrm{~cm}$. Berapakah nilai gizi yang dimiliki balita tersebut dalam menentukan status gizi anak tersebut?. Dalam pengerjaan mamdani terlebih dahulu menentukan fuzzyfikasi seperti dalam penyelesaian berikut:

Berdasarkan Rumus (2) untuk menghitung umur :

$$
\text { Umur/usia[1] }=(1-0) /(2-0)=1 / 2=0.5
$$

Berdasarkan Rumus (5) untuk menghitung berat badan :

$$
\text { Berat Badan }[4]=(4-0) /(5-0)=4 / 5=0.8
$$

Berdasarkan Rumus (12) untuk menghitung tinggi badan :

Tinggi badan $[50]=(50-40) /(60-40)=10 / 20=0.5$

Berdasarkan Rumus (20) untuk menghitung lingkar kepala :

$$
\text { Lingkar Kepala [37] }=(37-33) /(40-33)=4 / 8=0.5
$$

Jika umur 1 tahun dan berat badan $4 \mathrm{~kg}$ dan panjang badan $50 \mathrm{~cm}$ maka kondisi balita tersebut bisa dikategorikan gizi buruk. $=\min (0.5 ; 0.8 ; 0.5 ; 0.5)$ 


$$
\begin{aligned}
& =\min 0.5 \\
& =\max 0.8
\end{aligned}
$$

Dari aturan predikat yang ada dihasilkan daerah fuzzy, dapat dilihat seperti pada Gambar 8.

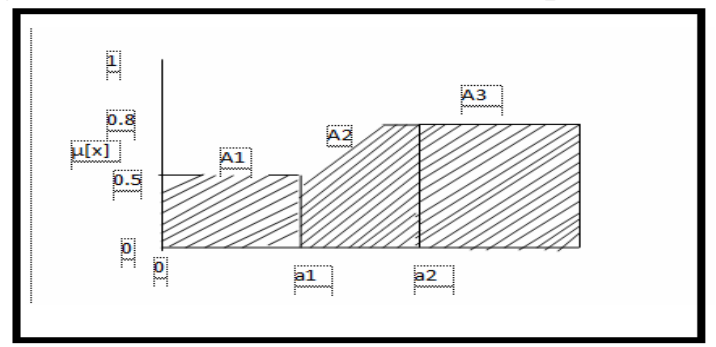

Gambar 8. Nilai Min dan Nilai Max

$(\mathrm{a} 1-0) / 100=0.5 \rightarrow 50$

$(\mathrm{a} 2-0) / 100=0.8->80$

Pada tahap selanjutnya adalah defuzzyfikasi dengan menggunakan Rumus (1), tahap ini menggunakan metode centroid.

$$
\begin{aligned}
Z^{*}=\frac{\int \mu(z) z d z}{\int \mu(z) d z} \\
Z^{*}=\frac{\int_{0}^{50} 0.5 z d z+\int_{50}^{50} \frac{(z-0) z d z}{100}+\int_{50}^{100} 0.8 z d z}{\int_{0}^{50} 0.5 d z+\int_{50}^{50} \frac{(z-0) d z}{100}+\int_{80}^{100} 0.8 d z} \\
Z^{*}=\frac{625+1290+1440}{25+19.5+16} \\
Z^{*}=\frac{3355}{60.5} \\
Z^{*}=55.45
\end{aligned}
$$

Setelah didapatkan hasil defuzzyfikasi, maka didapatkan nilai fuzzy $=55.45$, termasuk pada Gizi normal.

\subsection{Diagram Alir Data (DAD)}

\section{a. Diagram Konteks}

Berikut adalah alur diagram konteks bagi pengguna yang ditunjukkan pada Gambar 9, dapat dijelaskan bahwa penginputan data perhitungan gizi balita dilakukan oleh admin dengan memasukan data login, kelola variable, kelola perhitungan gizi dan setelah itu muncul daftar balita, setelah menginputkan data masuk pada system pendukung keputusan penanganan gizi pada balita ,setelah itu proses validasi login, data variable, dan hasil perhitungan dan daftar balita, yang kemudian data akan dijadikan hasil dari penanganan atau penentuan gizi pada balita yang diinput oleh admin.

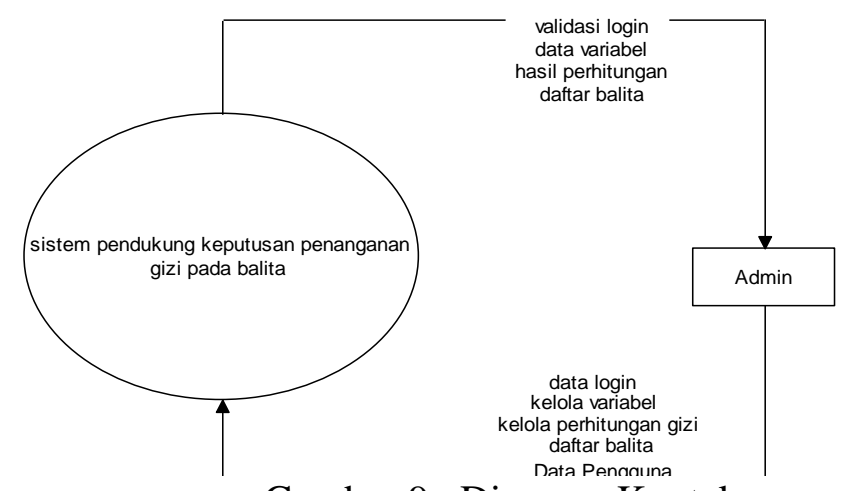

Gambar 9. Diagram Konteks 
b. DAD Level 0

Pada Gambar 10 dapat dijelaskan bahwa pada perancangan aplikasi sistem pendukung keputusan dalam penanganan gizi pada balita ini admin dapat menginputkan data balita dari daftar balita, nilai gizi, pengguna dan variabel, isi dari daftar balita berisi beberapa data balita yang sudah di tangani, nilai gizi berisi beberapa parameter atau batasan nilai untuk menentukan hasil dari perhitungan gizi, pengguna berisi beberapa data pengguna atau admin, variabel berisi beberapa variabel usia,variabel nilai, variabel lingkar kepala, variabel berat badan, dan variabel panjang badan, penggunaan diagram arus data berfungsi untuk menggambarkan arus data dalam sistem yang akan dibuat sesuai dengan permasalahan yang ada.

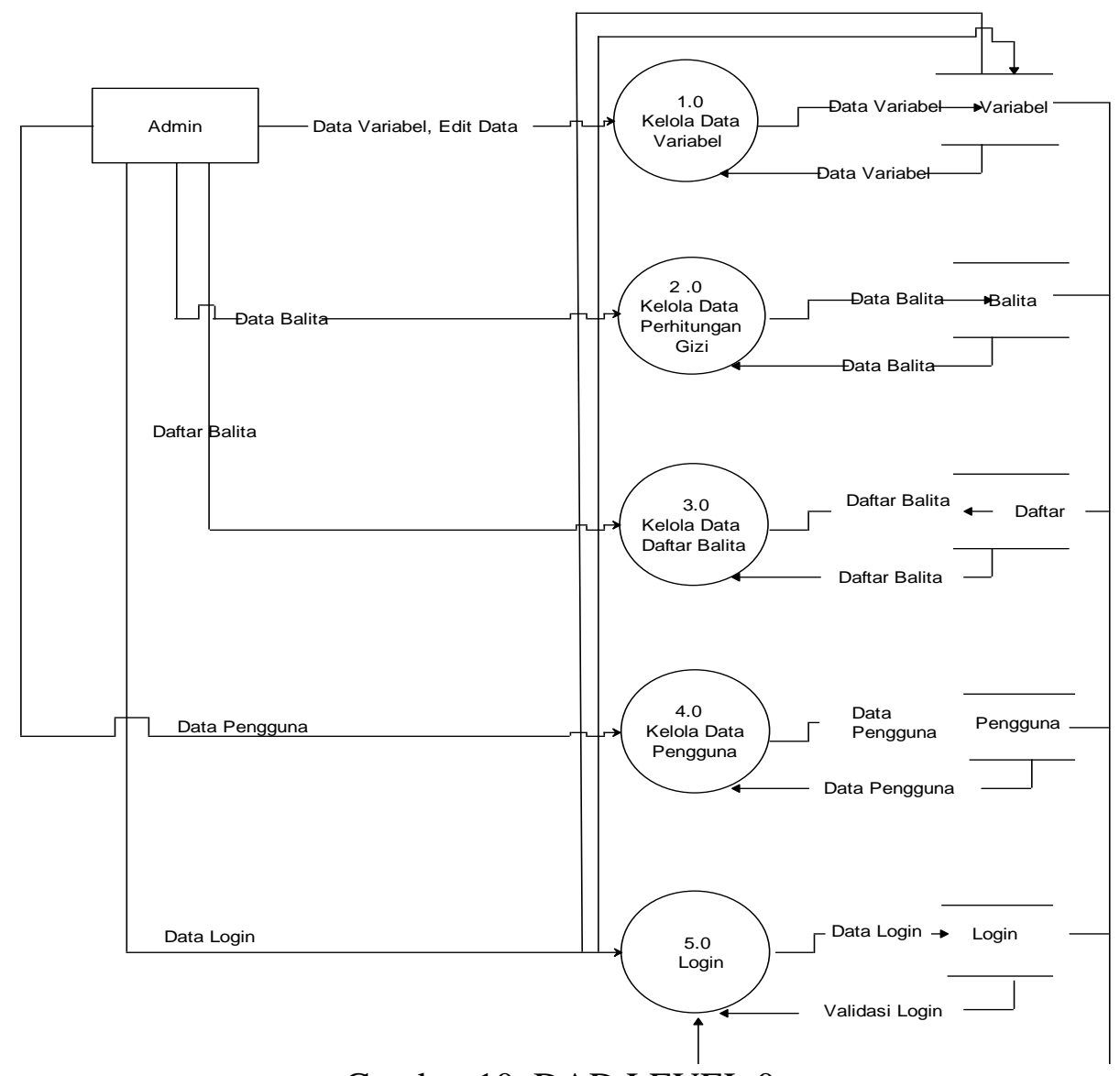

Gambar 10. DAD LEVEL 0

\subsection{Perancangan Basis Data}

Dalam pembuatan aplikasi sistem pendukung keputusan penanganan gizi pada balita ini dimaksudkan untuk lebih mudah melihat alur dari aplikasi. Adapun rancangan basis data yang ada pada sistem ini dapat dilihat Gambar 11 yang menunjukkan Entitas User mempunyai beberapa atribut berdasarkan setting paramaeter dengan entitas variabel derajat relasi many to many karena setiap entitas variabel dapat berhubungan dengan banyak entitas yang ada pada variabel demikianpun sebaliknya. Dari entitas variabel akan diproses dalam perhitungan nilai yang bersumber dari entitas data balita yang kemudian akan diproses untuk mendapatkan nilai pada proses perhitungan gizi. Kemudian hasil dari entitas nilai gizi akan menghasilkan entitas yang mana berelasi many to one dengan entitas pada daftar balita karena setiap lebih dari satu entitas nilai gizi dapat berhubungan dengan satu entitas pada data hasil dari data balita. 
Desain Tabel

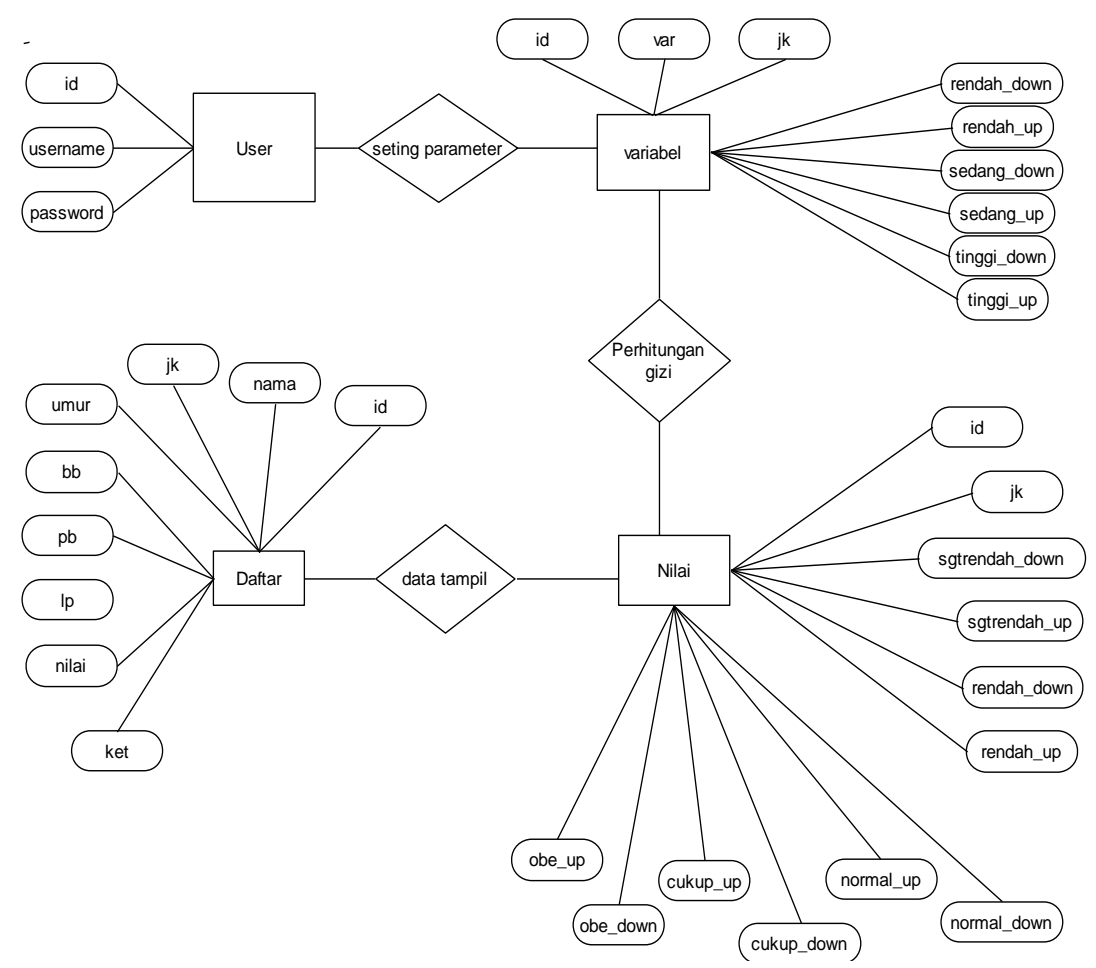

Gambar 11. ERD (Entity Relationship Diagram)

Desain tabel disini menggambarkan relasi antar tabel dalam sistem ini. Terdapat 4 tabel dalam sistem ini yaitu tabel user, variabel, nilai, daftar balita. Lebih jelasnya dapat dilihat pada Gambar 12.

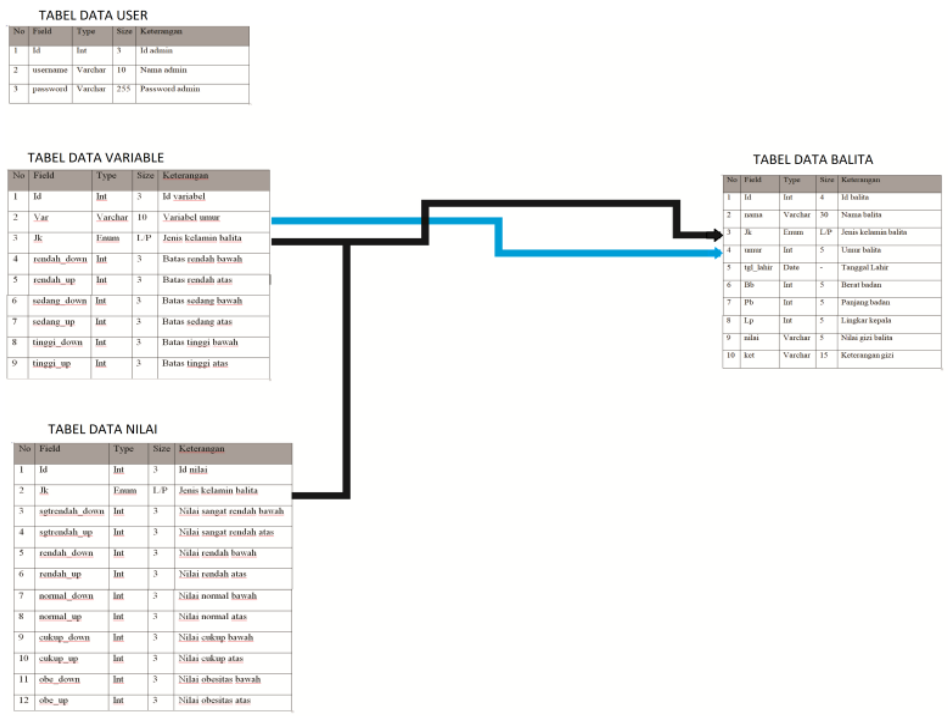

Gambar 12. Relasi Tabel

Pada Gambar 12, Warna biru menunjukan relasi antara tabel data variabel umur dengan data balita. Warna hitam menunjukan relasi antara tabel data nilai jenis kelamin dan data variabel dengan data balita.

\subsection{Implementasi}

Pada sistem pendukung keputusan penanganan gizi pada balita ini secara garis besar desain menu utamanya adalah sebagai berikut: 


\section{Beranda}

Langkah pertama dalam membuka homepage adalah membuka web browser, Kemudian pada address bar ketikan http://localhost/spk, setelah ditekan enter atau klik icon panah pada browser maka akan tampil halaman beranda dari sistem pendukung keputusan ini, pada halaman ini berisi ulasan tentang sistem pendukung keputusan dan sedikit pengetahuan dari beberapa jenis gizi pada balita. Adapun tampilan dapat dilihat pada Gambar 13.

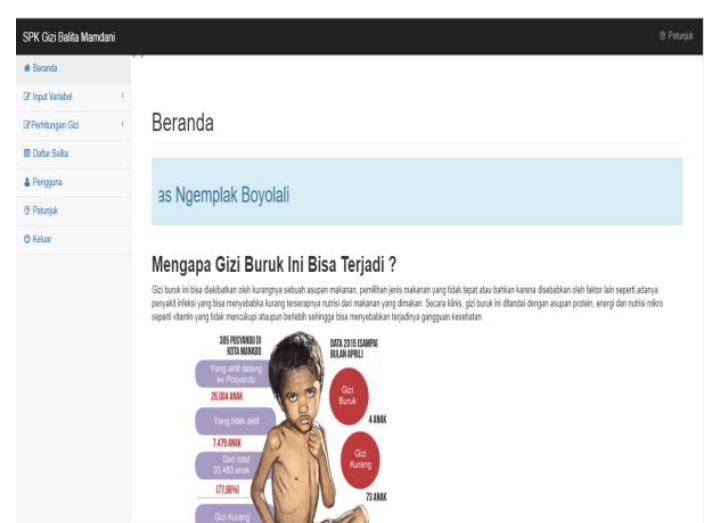

Gambar 13. Implementasi Halaman Beranda

2. Halaman Daftar Balita

Pada Gambar 14 adalah halaman daftar balita di aplikasi sistem pendukung keputusan penanganan gizi balita di Puskesmas Ngemplak Boyolali.

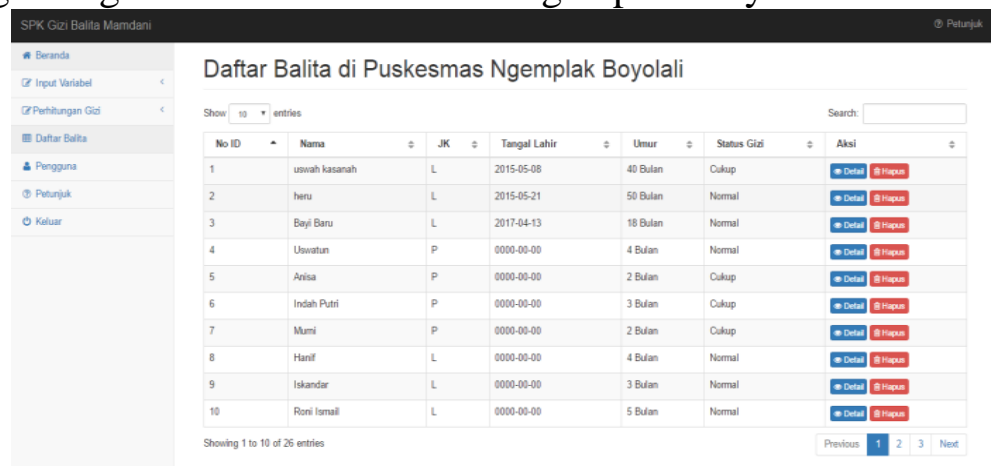

Gambar 14. Implementasi Daftar Balita

\section{Halaman Perhitungan Gizi Balita Laki-Laki}

Pada Gambar 15 menampilkan halaman perhitungan gizi balita laki - laki di aplikasi sistem pendukung keputusan penanganan gizi balita di Puskesmas Ngemplak Boyolali. 


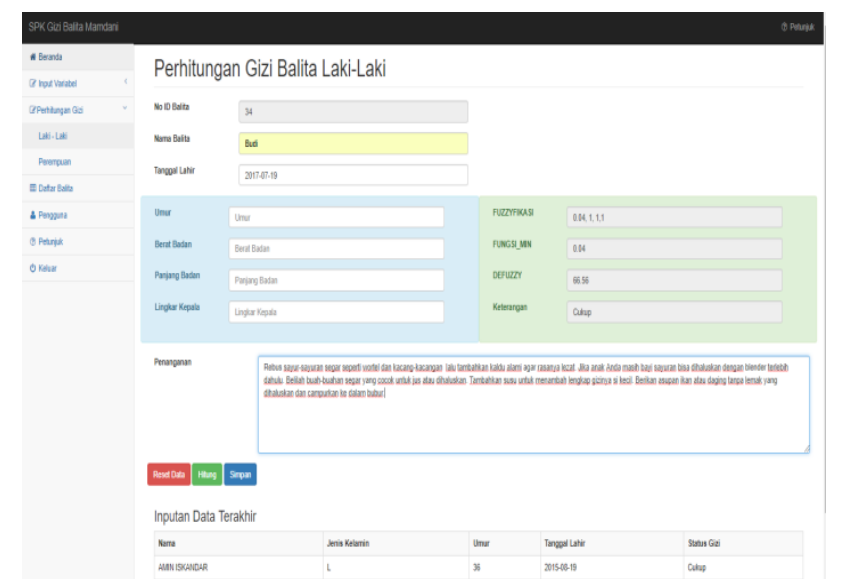

Gambar 15. Perhitungan Gizi Balita Laki-Laki

4. Halaman Perhitungan Gizi Balita Perempuan

Pada Gambar 16 menampilkan halaman perhitungan gizi balita Perempuan di aplikasi sistem pendukung keputusan penanganan gizi balita di Puskesmas Ngemplak Boyolali.

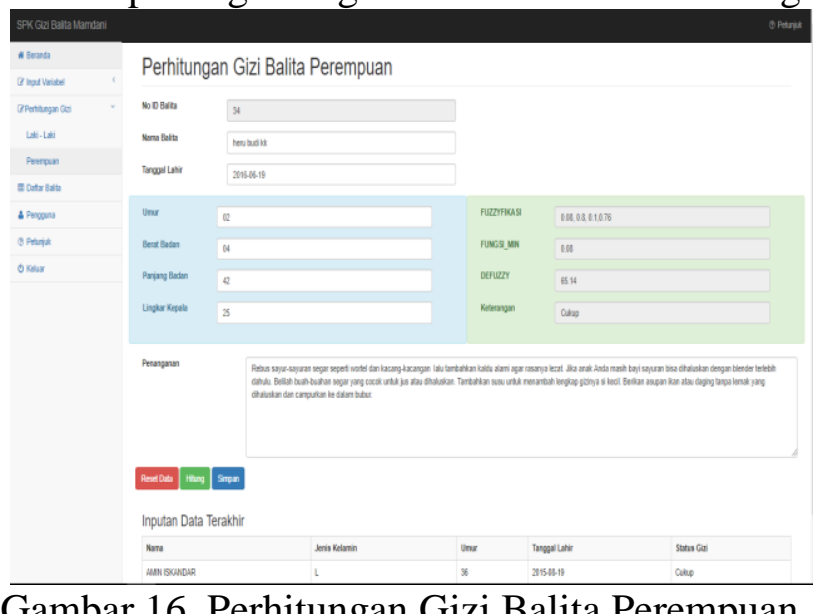

\subsection{Pengujian}

Pengujian yang dilakukan yaitu mencari akurasi perhitungan gizi balita dapat dilihat pada Tabel 1 dan Gambar 17. Pada Tabel 1 memperlihatkan hasil perbandingan sistem yang diusulkan dengan pakar. Gambar17 memperlihatkan komposisi hasil pengujian terhadap 18 data uji, yang mana grafik warna cokelat merupakan total data uji, grafik warna kuning menunjukkan 8 orang dengan gizi cukup, grafik warna merah menunjukkan 10 orang dengan gizi normal, grafik warna ungu 0 untuk gizi kurang, dan grafik warna biru 0 untuk gizi obesitas.

Tabel 1. Hasil Pengujian

\begin{tabular}{|l|l|l|l|l|l|l|l|l|c|}
\hline No & Kode & $\begin{array}{l}\text { Nama } \\
\text { Balita }\end{array}$ & JK & Umur & $\begin{array}{l}\text { Berat } \\
\text { Badan }\end{array}$ & $\begin{array}{l}\text { Panjang } \\
\text { Badan }\end{array}$ & $\begin{array}{l}\text { Lingkar } \\
\text { Kepala }\end{array}$ & $\begin{array}{l}\text { Ketera } \\
\text { ngan }\end{array}$ & $\begin{array}{c}\text { Hasil } \\
\text { Pengujian }\end{array}$ \\
\hline 1 & B1 & Rosa & P & 60 Bulan & $12 \mathrm{Kg}$ & $100 \mathrm{Cm}$ & $45 \mathrm{Cm}$ & Normal & Valid \\
\hline 2 & B2 & Kania & P & 48 Bulan & $11 \mathrm{Kg}$ & $95 \mathrm{Cm}$ & $40 \mathrm{Cm}$ & Normal & Valid \\
\hline 3 & B3 & Nisa & P & 24 Bulan & $10 \mathrm{Kg}$ & $75 \mathrm{Cm}$ & $36 \mathrm{Cm}$ & Cukup & Valid \\
\hline 4 & B4 & Nabila & P & 36 Bulan & $9 \mathrm{Kg}$ & $70 \mathrm{Cm}$ & $39 \mathrm{Cm}$ & Cukup & $\begin{array}{l}\text { Tidak } \\
\text { Valid }\end{array}$ \\
\hline 5 & B5 & Kaibatun & P & 48 Bulan & $12 \mathrm{Kg}$ & $72 \mathrm{Cm}$ & $44 \mathrm{Cm}$ & Cukup & Valid \\
\hline 6 & B6 & Ana & P & 24 Bulan & $14 \mathrm{Kg}$ & $68 \mathrm{Cm}$ & $37 \mathrm{Cm}$ & Cukup & $\begin{array}{l}\text { Tidak } \\
\text { Valid }\end{array}$ \\
\hline 7 & B7 & Zultan & L & 36 Bulan & $18 \mathrm{Kg}$ & $80 \mathrm{Cm}$ & $42 \mathrm{Cm}$ & Cukup & Valid \\
\hline
\end{tabular}




\begin{tabular}{|l|l|l|l|l|l|l|l|l|c|}
\hline No & Kode & $\begin{array}{l}\text { Nama } \\
\text { Balita }\end{array}$ & JK & Umur & $\begin{array}{l}\text { Berat } \\
\text { Badan }\end{array}$ & $\begin{array}{l}\text { Panjang } \\
\text { Badan }\end{array}$ & $\begin{array}{l}\text { Lingkar } \\
\text { Kepala }\end{array}$ & $\begin{array}{l}\text { Ketera } \\
\text { ngan }\end{array}$ & $\begin{array}{c}\text { Hasil } \\
\text { Pengujian }\end{array}$ \\
\hline 8 & B8 & Anggoro & L & 48 Bulan & $19 \mathrm{Kg}$ & $93 \mathrm{Cm}$ & $47 \mathrm{Cm}$ & Cukup & Valid \\
\hline 9 & B9 & Rizky & L & 60 Bulan & $20 \mathrm{Kg}$ & $102 \mathrm{Cm}$ & $48 \mathrm{Cm}$ & Cukup & $\begin{array}{l}\text { Tidak } \\
\text { Valid }\end{array}$ \\
\hline 10 & B10 & Febry & L & 48 Bulan & $17 \mathrm{Kg}$ & $94 \mathrm{Cm}$ & $46 \mathrm{Cm}$ & Normal & Valid \\
\hline 11 & B11 & Roni & L & 60 Bulan & $23 \mathrm{Kg}$ & $102 \mathrm{Cm}$ & $47 \mathrm{Cm}$ & Normal & Valid \\
\hline 12 & B12 & Iskandar & L & 36 Bulan & $14 \mathrm{Kg}$ & $85 \mathrm{Cm}$ & $43 \mathrm{Cm}$ & Normal & Valid \\
\hline 13 & B13 & Hanif & L & 48 Bulan & $18 \mathrm{Kg}$ & $95 \mathrm{Cm}$ & $46 \mathrm{Cm}$ & Normal & Valid \\
\hline 14 & B14 & Murni & P & 24 Bulan & $9 \mathrm{Kg}$ & $75 \mathrm{Cm}$ & $36 \mathrm{Cm}$ & Cukup & Valid \\
\hline 15 & B15 & Indah & P & 36 Bulan & $10 \mathrm{Kg}$ & $86 \mathrm{Cm}$ & $41 \mathrm{Cm}$ & Cukup & Valid \\
\hline 16 & B16 & Anisa & P & 24 Bulan & $11 \mathrm{Kg}$ & $73 \mathrm{Cm}$ & $35 \mathrm{Cm}$ & Cukup & Valid \\
\hline 17 & B17 & Uswatun & P & 48 Bulan & $14 \mathrm{Kg}$ & $94 \mathrm{Cm}$ & $45 \mathrm{Cm}$ & Normal & Valid \\
\hline 18 & B18 & Ruslan & L & 36 Bulan & $14 \mathrm{Kg}$ & $85 \mathrm{Cm}$ & $39 \mathrm{Cm}$ & Cukup & Valid \\
\hline
\end{tabular}

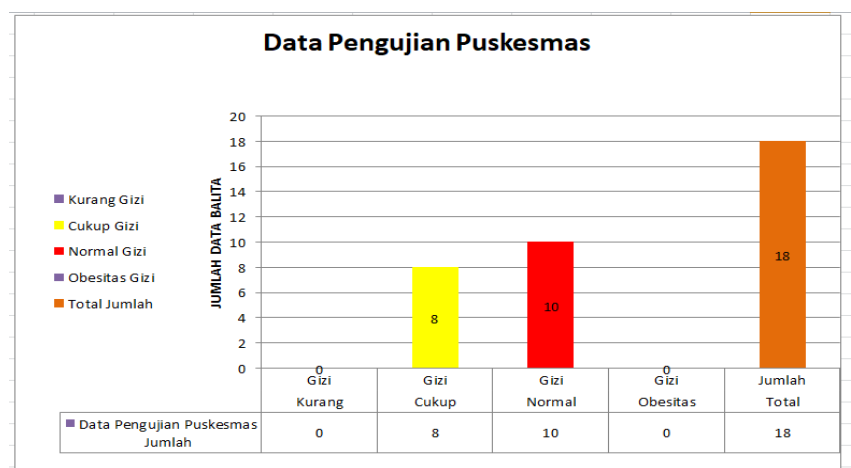

Gambar 17. Akurasi Perhitungan Gizi Balita

Dari Tabel 1 dapat diketahui bahwa: Jumlah data uji adalah 18, Jumlah diagnosa sistem yang benar adalah 15, Jumlah diagnosa sistem yang salah adalah 3 , sehingga Nilai akurasi $=15 / 18 \times 100 \%=83,33 \%$.

Oleh karena itu dapat disimpulkan bahwa akurasi sistem pakar menggunakan metode Fuzzy Mamdani berdasarkan 18 data penanganan gizi pada balita yang telah diuji mempunyai tingkat akurasi keberhasilan yang cukup baik sesuai dengan perhitungan sistem pendukung keputusan yaitu sebesar $83,33 \%$.

\section{KESIMPULAN DAN SARAN}

\subsection{Kesimpulan}

Berdasarkan keterangan di atas peneliti dapat menarik kesimpulan sebagai berikut:

1. Dari hasil penelitian dan perhitungan yang sudah dilakukan bahwa metode fuzzy mamdani ini sudah sesuai untuk diterapkan dalam penangan masalah gizi pada balita di Puskesmas Ngemplak Boyolali.

2. Aplikasi dengan perhitungan fuzzy mamdani ini dapat memberikan hasil yang akurat, dengan sistem yang lebih mudah agar dapat digunakan oleh para medis dalam proses penanganan gizi balita agar proses lebih cepat ditangani, dari hasil 18 data uji diperoleh akurasi sebesar $83,33 \%$.

\subsection{Saran}

Berdasarkan kesimpulan di atas, peneliti mengharapkan adanya:

1. Sebaiknya perkembangan lebih lanjut dapat dikembangkan dengan menambahkan variabel motorik balita.

2. Sebaiknya sistem yang dirancang kedepannya dapat dikembangkan lagi menjadi aplikasi yang dapat membantu menetukan penyakit anak jika mengalami gizi buruk. 


\section{DAFTAR PUSTAKA}

Damayanti, R., Setyaningsih, S., \& Qur'ania, A. (2014). Sistem Penunjang Keputusan Menentukan Status Gizi Pada Balita Dengan Menggunakan Metode Fuzzy. Bidang Ilmu Komputer Informatika , 1-7.

Dian, P. S., \& Sri. . (2015). Sistem Pendukung Keputusan Penentuan Status Gizi Buruk Pada Balita Menggunakan Metode Fuzzy Mamdani. Penelitian Bidang Komputer Sains dan Pendidikan Informatika, 1-7.

Hermaduanti, N., \& Kusumadewi, S. (2008). Sistem Pendukung Keputusan Berbasis SMS. (pp. 1-6). Yogyakarta: Universitas Islam Indonesia.

Ika, K. A., Fajar, S., \& Taufiq , H. (2007). Sistem Pendukung Keputusan Penanganan Kesehatan Balita. Seminar Nasional Aplikasi Teknologi Informasi , 1-7.

Kusumadewi, S., \& Purnomo, H. (2004). Aplikasi Logika Fuzzy Untuk Pendukung Keputusan. Yogyakarta: Graha Ilmu.

Lumbangaol, A., \& Rosaria. (2013). Sistem Pendukung Keputusan Penanganan Gizi Buruk Pada Balita Menggunakan Metode Fuzzy Mamdani. Pelita Informatika Budi Darma, , IV, 1-5.

Mubarok, MN \& Abadi, AM. (2015). Aplikasi Fuzzy Decision Making Dengan Menggunakan Metode Mamdani Penggandaan Dalam Pemilihan Smartphone. Seminar Nasional Matematika Dan Pendidikan Matematika UNY 2015 , 1-10.

Yokelin, T., Dharmaputra, P., \& Andeka, R. T. (2013). SPK Penentuan Tingkat Kerentanan Gizi Buruk. Jurnal Teknologi Informasi-Aiti , 10, 1-12. 